\title{
COMMENT
}

\section{PRIVATE SCHOOL DESEGREGATION UNDER SECTION 1981}

The practice of segregation in private schools vividly presents the conflict between claimed personal rights of privacy and free association on the one hand and the rights guaranteed and enforced by the thirteenth amendment ${ }^{1}$ and section 1981 of title 42 of the United States Code ${ }^{2}$ on the other. Two recent suits against segregated private schools under section 1981, McCrary v. Runyon ${ }^{3}$ and Riley v. Adirondack Southern School for Girls, ${ }^{4}$ reveal the need for a reexamination of the scope of that section.

Section 1981, formerly section 1 of the Civil Rights Act of $1866,{ }^{5}$ provides in part that "[a]ll persons ... shall have the same

${ }^{1}$ U.S. Const. amend. XIII provides:

"Section 1. Neither slavery nor involuntary servitude, except as a punishment for crime whereof the party shall have been duly convicted, shall exist within the United States, or any place subject to their jurisdiction. tion."

Section 2. Congress shall have power to enforce this article by appropriate legisla-

242 U.S.C. $\$ 1981$ (1970) provides:

All persons within the jurisdiction of the United States shall have the same right in every State and Territory to make and enforce contracts, to sue, be parties, give evidence, and to the full and equal benefit of all laws and proceedings for the security of persons and property as is enjoyed by white citizens, and shall be subject to like punishment, pains, penalties, taxes, licenses, and exactions of every kind, and to no other.

3515 F.2d 1082 (4th Cir. 1975) (en banc), aff'g in relevant part Gonzales v. FairfaxBrewster School, Inc., 363 F. Supp. 1200 (E.D. Va. 1973), cert. granted, 96 S. Ct. 354 (1975) (Nos. 75-62, 75-66, 75-278, 75-306). [Both the district and circuit court decisions hereinafter cited as McCrary.]

The district court opinion has been widely commented upon. See Note, Desegregation of Private Schools: Section 1981 as an Alternative to State Action, 62 GeO. L. J. 1363 (1974) [hereinafter cited as Alternative to State Action]; Note, The Desegregation of Private Schools: Is Section 1981 the Answer?, 48 N.Y.U.L. REv. 1147 (1973) [hereinafter cited as Is Section 1981 the Answer?); Comment, Jones v. Alfred H. Mayer Co. Extended to Private Education: Gonzales v. Fairfax-Brewster School, Inc., 122 U. PA. L. REv. 471 (1973) (favoring decision on state action ground) [hereinafter cited as Private Education]; 11 Houston L. REv. 691 (1974); 18 How. L. J. 458 (1974); 7 LoYola U.L. Rev. 634 (1974); 45 MIss. L.J. 246 (1974) (favoring reversal); 10 TuLSA L.J. 292 (1974); 42 U. Cin. L. REv. 767 (1973); 8 U. Richmond L. Rev. 285 (1974); 26 VAND. L. Rev. 1307 (1973).

4368 F. Supp. 392 (M.D. Fla. 1973), appeal docketed, No. 74-1976, 5th Cir., Apr. 15, 1974.

${ }^{5}$ Civil Rights Act of 1866 , ch. 31, 14 Stat. 27, reenacted, Enforcement Act of 1870, ch. $114, \S 18,16$ Stat. 144. 
right . . . to make and enforce contracts . . . as is enjoyed by white citizens ...." The section was enacted by Congress pursuant to its authority under the thirteenth amendment to outlaw slavery. It is unclear how far section 1981 extends, and, in particular, whether the section outlaws private school segregation. ${ }^{7}$ If the section is construed to prohibit such segregation, as it was in $M c C r a r y$, Congress may have exceeded its power to enforce the amendment by infringing constitutional rights to privacy and freedom of association, as guaranteed by the first amendment. This Comment will consider the significance of the claim, raised in both McCrary and Riley, that racial discrimination in private school admissions is a constitutionally protected activity. ${ }^{8}$ The recent Fifth Circuit decision in Cook v. Hudson ${ }^{9}$ will be considered in evaluating the constitutional interest, if any, in segregated private schools. ${ }^{10}$

The Comment will conclude that section 1981 as currently interpreted may constitutionally be applied to private schools. This Comment will also propose, however, a new interpretation of the section, somewhat analogous to the theory of mitigation of damages, which would strengthen the case for applying the statute to private schools by not denigrating vital associational

642 U.S.C. § 1981 (1970).

7 Much of the debate about the revival of $\S 1981$ and its companion, 42 U.S.C. $\S 1982$ (1970), revolves around the legislative history of these and other civil rights laws. See, e.g., Jones v. Alfred H. Mayer Co., 392 U.S. 409 (1968) (compare majority with dissenting opinions). This Comment will for the most part ignore the historical approach to interpretation of the statutes, in part because of adequate coverage elsewhere, and in part because the use of legislative history in this context is often not helpful when used only as a makeweight after evaluation of other issues.

${ }^{8}$ See generally Note, Section 1981 and Private Groups: The Right to Discriminate Versus Freedom from Discrimination, 84 YALE L.J. 1441 (1975). Some commentators have suggested that the proper method for attacking private school segregation is through use of a state action-public function analysis, e.g., Note, Segregation Academies and State Action, 82 Yale L.J. 1436 (1973) [hereinafter cited as Academies]; Private Education, supra note 3. These articles adequately cover most of the strengths and weaknesses of this approach. This Comment will not discuss the state action analysis, in part because of the prior treatment and in part because state action was not an issue actually addressed in the McCrary and Riley litigations. The shortcomings of the state action theory are most graphically set forth in Alternative to State Action, supra note 3, at 1366-69.

${ }^{9} 511$ F.2d 744 (5th Cir.), aff $g$ 365 F. Supp. 855 (N.D. Miss. 1973), petition for cert. filed, 44 U.S.L.W. 3230 (U.S. Oct. 1, 1975) (No. 75-503).

10 The district court opinion is commented upon in Comment, Cook v. Hudson: The State's Interest in Integration Versus the First Amendment Rights of the Public Schoolteacher, 45 Miss. L.J. 953 (1974) (favoring reversal); 6 N.C. CENT. L.J. 107 (1974). Text accompanying notes 101-15 infra. In Hudson, a divided court upheld a school board policy against hiring or rehiring teachers whose children attend private school. The school board adopted this policy to reinforce a court-ordered program of desegregation of the public school system. The case presents a variation of the conflict between asserted first amendment rights and rights to racial equality. 
and privacy rights which might be infringed by an unlimited application of section 1981. Section 1981 may be limited by requiring that the plaintiffs show actual injury in the market for education because of racial discrimination by the defendants; if alternative equivalent education is obtainable, no violation of section 1981 should be found. While section 1981 guarantees to nonwhites the same right to contract as whites, this right should be interpreted in light of the traditional requirement in the law of contracts that real injury in the marketplace be shown. ${ }^{11}$

\section{Attacks upon Private School Segregation: $M C C_{R A R Y}$ AND RILEY}

In Gonzales v. Fairfax-Brewster School, Inc., ${ }^{12}$ it was alleged that two black children were denied admission to defendant private schools because of their race in violation of section 1981 . The district court, finding that the schools' admissions policies reflected "no 'plan or purpose of exclusiveness' for selection of students 'other than race,",13 awarded damages for plaintiffs' humiliation and enjoined defendants from practicing racial discrimination in admissions in the future. ${ }^{14}$

The Court of Appeals for the Fifth Circuit affirmed in McCrary $v$. Runyon. ${ }^{15}$ Chief Judge Haynsworth wrote: "The section is violated by the school as long as the basis of exclusion is racial, for then it is clear that the black applicant is denied a contractual right which would have been granted to him if he had been white."16 At defendants' schools, there was a class of qualified applicants defined by "academic, financial, and other restrictions upon admission," but "[w]ithin the qualified class . . . there is no other limitation upon the admission of white applicants up to the school's capacity." ${ }^{17}$ That some whites were out-

"See, e.g., A. Corbin, Contracts $\$ \S 1039-44$ (1964).

12363 F. Supp. 1200 (E.D. Va. 1973), aff'd in relevant part sub nom. McCrary v. Runyon, 515 F.2d 1082 (4th Cir. 1975) (en banc), cert. granted, 96 S. Ct. 354 (1975) (Nos. 75-62, 75-66, 75-278, 75-306).

13363 F. Supp. at 1204 (quoting Sullivan v. Little Hunting Park, Inc., 396 U.S. 229, 236 (1969), which established that a private group that is not a "private club" under Title II of the 1964 Civil Rights Act, 42 U.S.C. $\$ 2000$ a et seq. (1970), is not exempt from 42 U.S.C. $\$ 1982(1970)$ ).

14 The injunction applied not only to the named defendant but also to the Southern Independent School Association, an intervening defendant. This Association alleged that it represents "over 300 private, non-profit schools in the South, some of which concededly are racially exclusive in their admission policies." 515 F.2d at 1084 .

15515 F.2d 1082 (4th Cir. 1975) (en banc), cert. granted, 96 S. Ct. 354 (1975) (Nos. 75-62, 75-66, 75-278, 75-306).

${ }^{16} 515$ F.2d at 1087.

${ }^{17}$ Id. 
side that class did not "undo" the section 1981 violation, the court reasoned, because the Supreme Court had found violations of section $1982,{ }^{18}$ whose scope closely parallels that of section 1981, in the segregation of private clubs that admitted all white persons up to the clubs' capacity. ${ }^{19}$

Judge Haynsworth disposed of the defendants' claim to associational and privacy rights by pointing out that the schools were free to teach whatever doctrines and to use whatever methods they wished. ${ }^{20}$ Moreover, these private groups could legitimately apply non-racial restrictions on admission, even if a racial imbalance in the student population resulted. The schools could not discriminate on the basis of race, however, ${ }^{21}$ notwithstanding the Supreme Court's speculation in Norwood v. Harrison that the "Constitution may compel toleration of private discrimination ...."22

The dissenting judges in $\mathrm{McCrary}$ made two important arguments. First, Judge Russell asserted that " $[t]$ he right to make and enforce contracts does not imply a right to coerce an unwilling co-contractor into making any and every variety of contract." ${ }^{23}$ In his view, Moose Lodge No. 107 v. Irvis, ${ }^{24}$ in which the right of a private club to discriminate was upheld even though it possessed a state liquor license, indicated that the unwilling co-contractor has the right to discriminate when important personal preferences are involved. Second, the dissent urged that the contractual features of application for admission to the defendant private schools were quite insubstantial so that the right to contract was in effect a pretense, a mere "door opener," to enable a court to reach the desired result.

Without endorsing the right of private schools to discriminate in admissions, the court in Riley v. Adirondack Southern School for Girls ${ }^{25}$ suggested a somewhat narrower application of section 1981 than did the McCrary majority. In Riley the plaintiff sought

${ }^{18} 42$ U.S.C. $\$ 1982$ (1970) provides: "All citizens of the United States shall have the same right in every State and Territory, as is enjoyed by white citizens thereof to inherit, purchase, lease, sell, hold, and convey real and personal property."

${ }^{19}$ Tillman v. Wheaton-Haven Recreation Ass'n, 410 U.S. 431 (1973); Sullivan v. Little Hunting Park, Inc., 396 U.S. 229 (1969).

20515 F.2d at 1087. The court relied on Pierce v. Society of Sisters, 268 U.S. 510 (1925).

21515 F.2d at 1088 .

22413 U.S. 455,463 (1973).

${ }^{23} 515$ F.2d at 1093 (Russell, Field \& Widener, JJ., dissenting).

24407 U.S. 163 (1972).

25368 F. Supp. 392 (M.D. Fla. 1973), appeal docketed, No. 74-1976, 5th Cir., Apr. 15, 1974. 
to enroll her black daughter in a private, all-white girls' school in Florida. The district court was "not persuaded that, but for her race the Plaintiff's child would have been accepted." 26 Therefore, while the court found that the evidence as a whole strongly suggested that race was one factor in the applicant's rejection, it denied relief. ${ }^{27}$

Both Riley and the dissent in McCrary tend to limit the application of section 1981 in suits against private segregated schools. In $M c$ Crary the dissent found a right in private schools to discriminate racially in their admissions process because of privacy and associational interests, and in Riley the court relied on a restrictive definition of causation. Neither case was actually decided on the basis of the claimed associational and privacy interests. These interests warrant closer examination as they are crucial to the formulation of more rational principles of construction for section 1981 .

\section{Section 1981 and Associational and Privacy Rights: An Overview}

The law of section 1981, of privacy, and of association have not yet been effectively synthesized. Before a synthesis can be attempted, some overview of the areas is necessary.

\section{A. The Right to Make and Enforce Contracts under Section 1981}

Two principal theories of the meaning of the phrase "the same right . . . to make and enforce contracts" 28 have been expressed in the cases and the literature.

${ }^{26} 368$ F. Supp. at 395 . On appeal, plaintiff-appellant will argue that the other reasons for rejecting her child were subterfuges for race, and that any other finding would be clearly erroneous. Brief for Appellant at 1 .

27368 F. Supp. at 395.

Riley may be consistent with $\mathrm{McCrary}$ in that the plaintiff in Riley failed to meet non-racial standards established by the school. By applying $M c C r a r y$ 's analysis, Riley need only have held that a violation of $\$ 1981$ occurs when a party is denied an opportunity to make a contract that he could have made had he been white, but that when racial bias may have been only incidentally appeased, no violation of $\$ 198 \mathrm{I}$ can be found. Indeed Riley itself states that "[u]nless it can be shown that, but for race the complainant would have succeeded [in making a contract], there is no denial of rights assured by $\S 1981$." Id. at 398 . A $\S 1981$ action can succeed only when race is found to be the sole element in the rejection of a student applicant. This explains why the court disregarded its finding that racial bias played a part in the decision to reject the applicant.

If, on the other hand, appellant in Riley is correct in asserting that race was the only factor in the decision to reject, the other factors being a subterfuge, then affirmance of the district court would be inconsistent with McCrary.

${ }^{28} 42$ U.S.C. $\$ 1981$ (1970). 
An early interpretation of the scope of section 1981 was given in Hodges $v$. United States. ${ }^{29}$ That case arose when a group of white men resorted to violence to prevent certain blacks from securing employment in a sawmill. The Supreme Court reversed the criminal conspiracy convictions which had been based on the violation of section 1981 rights, indicating that the acts of intimidation did not impose a condition of slavery upon their victims. Having reached this conclusion, the Court proceeded to describe the intended scope of section 1981 in terms of prohibition of government-imposed restrictions upon an individual's capacity to make contracts. ${ }^{30}$

This interpretation of section 1981 has been dealt three blows that must by now be deemed mortal. In Jones $v$. Alfred $H$. Mayer Co. ${ }^{31}$ a suit based on section 1982, defendant refused for reasons of race to sell a house to a prospective buyer who was black. The Supreme Court held that section 1982 reaches private discrimination and observed that section 1981 also applies to private discrimination, overruling Hodges to the extent of inconsistency. ${ }^{32}$ In Tillman $v$. Wheaton-Haven Recreation Association,${ }^{33}$ the Court again indicated that section 1981 is applicable to private dealings, but did not define the scope of that application. The demise of the state involvement approach was confirmed recently in Johnson v. Railway Express Agency, Inc., a suit in which plaintiff alleged employment discrimination under section 1981. The Supreme Court affirmed that section 1981 "affords a federal remedy against discrimination in private employment on the basis of race." 34 Clearly the approach taken before Jones $v$. Alfred $H$. Mayer Co. to interpreting "right to contract" can no longer serve as the basis for interpretation of this statute. ${ }^{35}$

29203 U.S. 1 (1906).

${ }^{30} \mathrm{Id}$. at 17-18. This was the traditional approach to interpretation of "right to contract." See, e.g., Lincoln Federal Labor Union v. Northwestern Iron \& Metal Co., 335 U.S. 525, 533-34 (1949); Lochner v. New York, 198 U.S. 45, 53-55 (1905); Allgeyer v. Louisiana, 165 U.S. 578, 590-91 (1897) (cases representing both sides of the "economic substantive due process" debate). See also California Drive-in Restaurant Ass'n v. Clark, 22 Cal. 2d 287, 295, 140 P.2d 657, 662 (1943); Mathewson v. Mathewson, 79 Conn. 23, 24-26, 63 A. 285, 286-87 (1906); Elder Chevrolet Co. v. Bailey County Motor Co., 151 S.W.2d 938, 942 (Tex. Civ. App. 1941).

31392 U.S. 409 (1968). See also Sullivan v. Little Hunting Park, Inc., 396 U.S. 229 (1969) (damage remedy for violation of $\S 1981$ ).

32 Id. at 441 n.78.

33410 U.S. 431 (1973).

3495 S. Ct. 1716, 1720 (1975).

${ }^{35}$ For a discussion of this theory and its demise, see Alternative to State Action, supra note 3 , at $1370-73$ \& sources cited in id. 1370 n.33. 
The holdings in $\mathrm{McCrary}{ }^{36}$ and Riley ${ }^{37}$ illustrate the second major approach to section 1981, predominant since Jones, in holding that the section is violated when a nonwhite cannot make a contract he could have made had he been white. The novelty of these holdings lies only in their application to completely private schools. ${ }^{38}$ Several courts of appeals had reached similar results prior to $M c C r a r y$ and Riley in several cases involving employment contracts ${ }^{\mathbf{3 9}}$ and in a case involving a privately owned recreation area. ${ }^{40}$ As noted above, the Supreme Court held in Johnson v. Railway Express Agency, Inc. that section 1981 applies to private discrimination in employment. ${ }^{41}$ But the Court there had no occasion to endorse or reject the standard ultimately articulated in $\mathrm{McCrary}$ and Riley defining violation of section 1981. There is, however, nothing in Johnson to indicate a more restrictive interpretation.

This more recent line of reasoning is quite expansive. Section 1981 so interpreted applies to the entire body of relationships that may be defined as contractual. Whether the relationship is business or personal is not, according to this view, important. ${ }^{42}$ This interpretation may be limited by strict definition of what is a contract. For example, the Court of Appeals for

${ }^{36}$ McCrary v. Runyon, 515 F.2d 1082 (4th Cir. 1975) (en banc), cert. granted, 44 U.S.L.W. 3279 (U.S. Nov. 11, 1975) (Nos. 75-62, 75-66, 75-278, 75-306).

${ }^{37}$ Riley v. Adirondack Southern School for Girls, 368 F. Supp. 392 (M.D. Fla. 1973), appeal docketed, No. 74-1976, 5th Cir., Apr. 15, 1974.

${ }^{38}$ The schools in these suits received no government funding nor special favors. Section 1981 had already been applied to a private trade school in Grier v. Specialized Skills, Inc., 326 F. Supp. 856 (W.D.N.C. 1971), but the court there held that the fact that the trade school had to be licensed by the state and that all such state-licensed schools were segregated (two out of five all black) impermissibly involved the state in the affairs of the school. Further, some of the school's students received federal aid.

${ }^{39}$ Long v. Ford Motor Co., 496 F.2d 500 (6th Cir. 1974); Brown v. Gaston County Dyeing Mach. Co., 457 F.2d 1377 (4th Cir.), cert. denied, 409 U.S. 982 (1972); Young v. International Tel. \& Tel. Co., 438 F.2d 757, 758-60 (3d Cir. 1971); Boudreaux v. Baton Rouge Marine Contracting Co., 437 F.2d 1011, 1016-17 (5th Cir. 1971) (following Sanders v. Dobbs Houses, Inc., 431 F.2d 1097, 1099-1100 (5th Cir. 1970), cert. denied, 401 U.S. 948 (1971)); Waters v. Wisconsin Steel Works, 427 F.2d 476, 481-84 (7th Cir.), cert. denied, 400 U.S. 911 (1970).

${ }^{40}$ Scott v. Young, 421 F.2d 143 (4th Cir.), cert. denied, 398 U.S. 929 (1970) (alternate holding); see Olzman v. Lake Hills Swim Club, 495 F.2d 1333 (2d Cir. 1974) (swimming club's rules were alleged to be racial subterfuges).

$4195 \mathrm{~S}$. Ct. 1716, 1720 (1975). Johnson held that $\S 1981$ is a remedy for job discrimination entirely separate from Title VII of the 1964 Civil Rights Act, 42 U.S.C. $\$ 2000 \mathrm{e} e t$ seq. (1970), and that therefore an action in the Equal Employment Opportunity Commission under that title does not toll the statute of limitations applicable to $\S 1981$.

42 But see Buchanan, Federal Regulation of Private Racial Prejudice: A Study of Law in Search of Morality, 56 IowA L. REv. 473, 506-12 (1971). 
the Fifth Circuit held in Cook v. Advertiser Co. ${ }^{43}$ that a standing opportunity to publish social notices in a newspaper, without charge, does not amount to an offer of a unilateral contract, so that one denied publication on racial grounds has no cause of action under section 1981. Neither whites nor blacks, the court reasoned, can claim a contract right to have notices published. ${ }^{44}$

Apart from $\mathrm{McCrary}$, only district courts have considered the right of privacy as a principle possibly limiting section $1981 .^{45} \mathrm{~A}$ reason for limiting application of the section is to prevent the danger, somewhat overstated by the McCrary dissenters, that unwilling co-contractors will be coerced into any and every variety of contract, ${ }^{46}$ thus changing the effective definition of contract from a meeting of the minds (subject to legitimate government regulation) to a meeting of the minds on all subjects except race. ${ }^{47}$ The logic of this line of reasoning has been considered by many commentators ${ }^{48}$ and will be discussed below in terms of the conflict between section 1981 and first amendment and related constitutional liberties.

\section{B. Associational and Privacy Rights}

The Supreme Court has never addressed itself to the problem of clearly defining or even stating a formula for associational

43458 F.2d 1119 (5th Cir. 1972), aff'g 323 F. Supp. 1212 (M.D. Ala. 1971).

${ }^{44}$ For purposes of this Comment, Judge Wisdom's concurring opinion is more interesting than the majority opinion. Judge Wisdom's conclusion that the Advertiser's solicitation of information about social events and responses to that solicitation did not constitute a contract was

shaped by, if not compelled by, the First Amendment's guarantee of a free press. It is most unlikely that any court in our land could constitutionally enforce a promise by a newspaper to publish any particular item of news [citing Shelley v. Kraemer, 334 U.S. 1 (1948)]. Even if a newspaper stooped to sell its news coverage for hard cash, I suppose the most a frustrated buyer would be entitled to would be a refund of the dollars he had parted with.

458 F.2d at 1123 (Wisdom, J., concurring). But see Pittsburgh Press Co. v. Pittsburgh Comm'n on Human Relations, 413 U.S. 376 (1973) ("commercial speech," here in the form of sex-segregated want ads, not protected by the first amendment) (5-4 decision, Burger, C.J., and Douglas, Stewart and Blackmun, JJ., dissenting).

${ }^{45}$ See, e.g., Cornelius v. Benevolent Protective Order of Elks, 382 F. Supp. 1182, 1198 (D. Conn. 1974) ( $\$ 1981$ found unconstitutional if read with no limits, but "saved" by "harmonization" with the private club exemption of Title II of the 1964 Civil Rights Act, 42 U.S.C. \& 2000a(e) (1970), by exempting private clubs from $\$ 1981$ as well); Sims v. Order of United Commercial Travelers, 343 F. Supp. 112 (D. Mass. 1972).

${ }^{46}$ Text accompanying note 23 supra.

47 Of course, it can be said that any limitation on power to bargain inserts an element of unwillingness into the subsequent deal. $C f$. Lochner v. New York, 198 U.S. 45 (1905); Allgeyer v. Louisiana, 165 U.S. 578 (1897) (discredited "substantive due process" cases).

${ }^{48}$ E.g., Buchanan, supra note 42; Note, Federal Power to Regulate Private Discrimination: The Revival of the Enforcement Clauses of the Reconstruction Era Amendments, 74 Colum. L. 
and privacy rights. The following will point out those decisions that may be useful in synthesizing a definition of these rights needed to dispose of the cases at hand.

\section{The Right of Association ${ }^{49}$}

Except for "the right of the people peaceably to assemble, and to petition the Government for a redress of grievances,"50 freedom of association is not specifically set forth in the Constitution. The development of associational rights in the Supreme Court has been largely dependent on the kind of situation in which the issue has arisen. It is not clear in any given case precisely what considerations the Court will take into account, in developing the doctrine further. The factual settings of McCrary and Riley have not yet been dealt with by the Court.

At the very least, private schools have a right to exist and to teach whatever subjects and doctrines not "manifestly inimical to the public welfare" they wish. ${ }^{51}$ The right to control their own activities is not unlimited, but is susceptible to reasonable regulation concerning the compulsory teaching of certain subjects and the qualifications of teachers. ${ }^{52}$ (Private schools do not, however, have the right to discriminate on the basis of race while receiving federal or state assistance.) ${ }^{53}$ Whatever additional rights private schools may have must be deduced from decisions regarding associational and privacy rights in other contexts and from general constitutional and ethical principles.

The right to associate for political purposes has been defined broadly and has been given protection in a number of contexts. One case in which the right to associate was raised, NAACP v. Alabama ex rel. Patterson, ${ }^{54}$ held that a nonsubversive political organization need not reveal its membership list to the

Rev. 449 (1974); Is Section 1981 the Answer?, supra note 3, at 1153-75; Private Education, supra note 3.

${ }^{49}$ See generally C. Rice, Freedom of Association (1962); Emerson, Freedom of Association and Freedom of Expression, 74 YALE L.J. 1 (1964); Nathanson, Freedom of Association and the Quest for Internal Security: Conspiracy from Dennis to Dr. Spock, 65 Nw. U.L. REv. 153 (1970).

so U.S. Const, amend. I.

51 Pierce v. Society of Sisters, 268 U.S. 510, 534 (1925); see Meyer v. Nebraska, 262 U.S. 390 (1923); Bartels v. Iowa, 262 U.S. 404 (1923) (both striking down statutes forbidding teaching languages to school children of certain ages).

52268 U.S. at 534.

${ }^{53}$ E.g., Gilmore v. City of Montgomery, 417 U.S. 556 (1974); Norwood v. Harrison, 413 U.S. 455 (1973); Green v. Connally, 330 F. Supp. 1150 (D.D.C.), aff'd per curiam sub nom. Coit v. Green, 404 U.S. 997 (1971); Griffin v. County School Bd., 377 U.S. 218 (1964). 
government when there is some possibility that doing so would expose some of its members to adverse community pressures and when the state could accomplish its aim in requiring such a list less intrusively. Alabama proposed to use the lists to determine violations of the state's foreign corporation statutes. On the other hand, in Communist Party v. Subversive Activities Control Board $^{55}$ the Court upheld the federal government's interest in requiring Communist Party members to register with the government on the basis of a legislative finding that foreigndominated Communist activities posed a substantial threat to the national security. ${ }^{56}$ Even when one is a member of a subversive organization, however, he must specifically intend to promote such of the organization's aims as are illegal if he is to be penalized. ${ }^{57}$

Important to an analysis of the private school segregation issue is the broad scope that has been given the term "political association." The Supreme Court has not limited the term "political activity" to the narrowly electoral, or even to the promotion of ideology through speech and associated media. NAACP $v$. $B$ utton ${ }^{58}$ held that a Virginia antichamperty law could not apply to the NAACP's efforts to secure legal assistance for poor blacks, because of the organization's associational rights.

The NAACP is not a conventional political party; but the litigation it assists, while serving to vindicate the legal rights of members of the American Negro community, at the same time and perhaps more importantly, makes possible the distinctive contribution of a minority group to the ideas and beliefs of our society. For such a group, association for litigation may be the most effective form of political association. ${ }^{59}$

Against this associational right, the state's claimed interest in preventing misuse of the courts could not stand. ${ }^{60}$

55367 U.S. 1 (1961).

${ }^{56} \mathrm{~A}$ subsequent case rendered the registration requirement invalid on the ground that it violated the fifth amendment privilege against self-incrimination. Albertson $v$. Subversive Activities Control Bd., 382 U.S. 70 (1965). In Aptheker v. Secretary of State, 378 U.S. 500 (1964), the denial of passports to Communist Party members who failed to register was invalidated for overbreadth, in part because it could be applied to one who did not know or did not intend the Party's illegal aims.

${ }^{57}$ See Elfbrandt v. Russell, 384 U.S. 11 (1966); De Jonge v. Oregon, 299 U.S. 353 (1937).

58371 U.S. 415 (1963).

${ }^{59}$ Id. at 431 .

${ }^{60}$ Justice Douglas, concurring, noted that the purpose of the law in question was to 
An individual may not be punished for teaching a doctrine, even a code of violence, absent a clear and present danger. ${ }^{61}$ Presumably an individual or a group may not be punished for banding together to learn such a doctrine or even to spread it. One court of appeals has held that protection of political association requires that segregated political groups be given the same opportunity to use state-owned facilities on a temporarily exclusive basis as is given other political groups. ${ }^{62}$

Much of the law of free association concerns governmental restrictions on public employees. The leading cases permitting such restrictions, United Public Workers v. Mitchell ${ }^{63}$ and United States Civil Service Commission v. National Association of Letter Carriers, ${ }^{64}$ upheld enforcement of the Hatch Act, restricting the right of federal employees to engage in partisan political activities. Other cases, however, have protected the rights of government employees to engage in associational activities that are political in a broad sense of that term but are not partisan in the sense of the dominant two-party system. United States v. Robel ${ }^{65}$ held that Congress cannot make it a crime to belong to an officially designated Communist-action organization while working in a defense plant; but the Court conceded that the result might be different if the statute required proof of specific intent to engage in the unlawful activities such an organization might promote. ${ }^{66}$ But absent a strong countervailing governmental interest the right of public employees to associate may not be infringed. This is clear from Shelton v. Tucker ${ }^{67}$ in which the Court held that Arkansas may not require its schoolteachers to file annual affidavits, listing all current and recent organizational ties, for the purpose of assessing the teachers' fitness.

There is also some constitutional protection of social, nonpolitical association, but whether it is as great as protection of

resist the mandate of Brown v. Board of Educ., 347 U.S. 483 (1954) by penalizing the NAACP because it promotes desegregation. Id. at 445 .

${ }^{61}$ Brandenburg v. Ohio, 395 U.S. 444 (1969). Justices Black and Douglas would not recognize a "clear and present danger" exception. Id. at 449-57 (Black \& Douglas, JJ., concurring).

${ }^{62}$ National Socialist White People's Party v. Ringers, 473 F.2d 1010 (4th Cir. 1973) (en banc) (successor to the American Nazi Party was allowed to rent a public school auditorium, often used for political discussion, for a public meeting and a private meeting, over the objections of the county that this activity would impermissibly involve it in discriminatory action because blacks and Jews were to be excluded).

63330 U.S. 75 (1947).

64 413 U.S. 548 (1973).

${ }^{65} 389$ U.S. 258 (1967).

${ }^{66} I d$. at 262-63.

${ }^{67} 364$ U.S. 479 (1960). 
political association is unclear. The strongest recent support for such rights is provided in two cases concerning appropriate means of implementing desegregation orders. In Norwood $v$. Harrison the Court speculated that "the Constitution may compel toleration of private discrimination . . . ."68 However, the Court did not conclude that the Constitution does in fact compel such toleration. ${ }^{69}$ The Court voiced this concern in Gilmore v. City of Montgomery, in refusing to restrict certain uses of public parks by segregated groups: "The freedom to associate applies to the beliefs we share, and to those we consider reprehensible."70 This result was based on the absence of state action, but the Court had in mind potential encroachments upon discriminatory groups' associational rights. Significantly, the Supreme Court has not yet held these rights to include the right to exist as a racially discriminatory group, ${ }^{71}$ although several lower courts have done so. ${ }^{72}$

There is a hint, but only a hint, that associational rights do not include a right to associate on the basis of race or, alternatively, that such associations merit less protection than others because of the spirit of the post-Givil War amendments. The McCrary opinion states that some schools may be "so private as to have a discernible rule of exclusivity which is inoffensive to $\S$ 1981."73 The principle of exlusivity would have to be racially neutral, however, to be inoffensive, as, for example, if siblings retained a tutor for their children. ${ }^{74}$

Shelley v. Kraemer ${ }^{75}$ and Barrows v. Jackson ${ }^{76}$ lend support to the position that segregation is not a protected form of association. A group of people may agree to associate by living together as a community and may use the device of enforceable property convenants to ensure the group's cohesiveness. (For example, covenants requiring that lawns be mowed regularly and houses maintained can be seen as an effort by the co-covenantors to

68413 U.S. 445,463 (1973).

${ }^{69}$ But see Moose Lodge No. 107 v. Irvis, 407 U.S. 163, 179 (1972) (Douglas, J., dissenting).

70417 U.S. 556, 575 (1974).

${ }^{71}$ Note that the question of a club's right to exist as a segregated organization is distinct from what rights extent clubs have.

72 See cases cited note 45 supra.

${ }^{73}$ McCrary v. Runyon, 515 F.2d 1082 (4th Cir. 1975) (en banc), cert. granted, 96 S.

Ct. 354 (1975) (Nos. 75-62, 75-66, 75-278, 75-306).

${ }^{74} 515$ F.2d at 1088-89.

75334 U.S. 1 (1948).

76346 U.S. 249 (1953). 
associate only with people who care about their surroundings. ${ }^{77}$ ) Race is not a characteristic that the group may use in defining itself, however, if it wishes to enforce a convenant restricting the sale of property. Since Jones $v$. Alfred H. Mayer Co.,${ }^{78}$ even voluntary cooperation in maintaining a segregated community is impermissible, because a prospective purchaser has a remedy against the discriminatory seller. Indeed, it is possible that the right of association, "penumbral" to begin with, is dimmed further by the post-Civil War amendments. This Comment is concerned with more than the shadowing of the right of association by the post-Civil War amendments; it is concerned with the possibility of the right's total eclipse.

\section{The Right of Privacy}

Cases defining the growing area of privacy ${ }^{79}$ or what might be described as autonomy ${ }^{80}$ of person and family also contribute to the theory of the rights of private schools. This area was recognized in 1925 in Pierce $v$. Society of Sisters, ${ }^{81}$ in which the Court invalidated a state law requiring children to attend public school because the law abridged "the liberty of parents . . . to direct the upbringing and education of [their] children . . .."82 The notion has undergone its greatest development in four cases decided in the last decade, Griswold $v$. Connecticut, ${ }^{83}$ Stanley $v$. Georgia,$^{84}$ Eisenstadt $v$. Baird, ${ }^{85}$ and Roe v. Wade. ${ }^{86}$ The principle common to these cases is that certain aspects of one's life are so personal that direct governmental encroachment is constitutionally impermissible.

For purposes of analyzing the privacy problems in the private school setting, Griswold is the most important of the four values.

${ }^{77}$ Of course this might also evidence a financial concern with maintaining property

78392 U.S. 409 (1968).

${ }^{79}$ See generally Henkin, Privacy and Autonomy, 74 Colvm. L. Rev. 1410 (1974); Warren \& Brandeis, The Right to Privacy, 4 HARv. L. REv. 193 (1890); Symposium-Privacy, 31 LaW \& Contemp. Prob. 251 (1966); Note, On Privacy: Constitutional Protection for Personal Liberty, 48 N.Y.U.L. Rev. 670, 697-705 (1973) [hereinafter cited as On Privacy].

${ }^{80}$ See notes $142-77$ infra \& accompanying text.

81268 U.S. 510 (1925).

${ }^{82} \mathrm{Id}$. at $534-35$.

${ }^{83} 381$ U.S. 479 (1965) (decision to use contraceptives is a penumbral right for married couples).

${ }^{84} 394$ U.S. 557 (1969) (right to have pornography in the privacy of one's home).

${ }^{85} 405$ U.S. 438 (1972) (equal protection requires that the availability of contraceptives not be dependent on marital status).

${ }^{86} 410$ U.S. 113 (1973) (abortion). 
decisions because it protects a particular intrafamilial relationship, marriage, from certain governmental interference. The Court in Griswold held that the state may not deny to a married couple the right to choose whether or not to use contraceptives. ${ }^{87}$ The Court based its holding on several constitutional principles, primarily the first amendment and its penumbras but also the third, fourth, fifth, ninth, and fourteenth amendments, all of which contain guarantees against governmental interference with various aspects of an individual's life. The majority relied on Pierce to support its holding, ${ }^{88}$ suggesting that intrafamilial relationships other than the conjugal one share the same type of protection.

The other three decisions bear less directly on the privacy rights accorded specific family relationships, but do concern the general right of individuals to be free from governmental interference in matters of personal choice, particularly those related to sexuality. In Stanley $v$. Georgia, ${ }^{89}$ the Court held that although publication and sale of pornography may be unprotected by the first amendment, the possession of obscene material for use in the privacy of one's home is protected as part of the right of freedom of thought. In Roe v. Wade, ${ }^{90}$ as in Griswold, the decision to have a child was considered, this time in light of the woman's particular problems as a childbearer. The private nature of this decision was found to outweigh many state interests previously believed to be of overriding importance. In Eisenstadt,,$^{91}$ the right of unmarried persons to the same freedom of access to contraceptives as that possessed by married people was established.

That these cases do not bear directly on the relationship between parent and child and the decisionmaking aspects of that relationship does not imply that the parent-child relationship is not protected by the Constitution. To the contrary, Pierce demonstrates that the relationship is protected and Griswold, Stanley, Eisenstadt, and Roe v. Wade reinforce and expand the Pierce approach by upholding penumbral rights of privacy in intimate relationships or deeply personal choices. ${ }^{92}$

${ }^{87}$ Note that there are limits even to this freedom, for there is little question that contraception may be limited in certain ways, as by prohibition of a harmful drug.

88381 U.S. at $481-83$.

${ }^{89} 394$ U.S. 557 (1969).

90410 U.S. 43 (1973).

${ }^{91}$ Eisenstadt v. Baird, 405 U.S. 438 (1972).

${ }^{92}$ In Wisconsin v. Yoder, 406 U.S. 205 (1972), the parent-child relationship was protected against the state's interference in the context of a decision concerning how much education was enough for the child. That decision was based primarily on the right 


\section{Limiting Principles for Section 1981}

The ultimate resolution of the issues raised in $M c C r a r y$ and Riley will depend on the limiting principles devised for use in section 1981 cases. This section will deal with several possible principles for limiting the section, raising issues of both statutory and constitutional dimension.

\section{A. The "Door Opener" Argument}

The dissenting judges in $\mathrm{McCrary}$ asserted that in the private school context " $[\mathrm{t}]$ he contract aspect of the situation is minor and incidental and serves no purpose other than as a door opener in the present case to bring independent schools within the scope of $\S 1981 . " 93$ This is so, the dissent believed, because the student-teacher relationship is one of status rather than contract and is "related to the contract concept in the same way that the status of husband and wife may be said to grow out of a contract ...."94 These situations were distinguished from that of Jones $v$. Alfred H. Mayer Co. ${ }^{95}$ because the property transactions denied in Jones in violation of section 1982 were "purely commercial," with a basis in contract and not in status. ${ }^{96}$

It is clear, however, that there is a more than token contractual basis in the relationship between a school on the one hand and a parent or child ${ }^{97}$ on the other. The parent enters into a binding contract with the school to pay for services and perhaps

to the free exercise of religion, however, and absent the religious element it is unlikely that the Court would hold that a parent may disregard a compulsory attendance law. See generally Pierce v. Society of Sisters, 268 U.S. 510, 534 (1925).

Of course, other cases exist defining the protection given to one or another aspect of the individual's private life, most notably protection from criminal investigations that invade one's privacy, e.g., Terry v. Ohio, 392 U.S. 1 (1968); Katz v. United States, 389 U.S. 347 (1967). These cases add to the spirit of the law bearing on the cases under discussion, but are not directly relevant to the problem of the freedom to be unencumbered in intimate relationships and associations.

${ }^{93} 515$ F.2d at 1093 (Russell, Field \& Widener, JJ., dissenting).

${ }^{94} \mathrm{Id}$. at 1092-93 (Russell, Field \&Widener, JJ., dissenting).

95392 U.S. 409 (1968). See text accompanying notes 31-33 supra.

${ }^{96} 515$ F.2d at 1093 (Russell, Field \& Widener, JJ., dissenting).

${ }^{97}$ In the ordinary case, the child does not contract directly with the teacher, but this is essentially because the child makes none of his own contracts in matters of substance. Justice Douglas' dissenting opinion in Wisconsin v. Yoder, 406 U.S. 205 (1972), suggests that the child has some right to determine whether and where he wishes to go to school. Id. at 244-46 (Douglas, J., dissenting in part). If the child's role as a decisionmaker is accepted, the contract between the young student and the teacher clearly will be established. The corresponding relationship of an adult student to a college, for instance, involves the acceptance of mutual obligations and rights and not merely the subordination of the student to the teacher. In the case of the young student this consensual relationship is not as clear, because of the seeming split of the child's legal personality between himself and his parents. 
to perform other duties (such as ensuring the promptness and neat appearance of his child) in return for the provision of education. The period during which a student applies for admission and chooses among schools is clearly a contract formation period. Before the relationship of teacher and pupil ensues, an agreement to teach and to send one's child to learn, in return for a consideration, is required. Providing teachers, curricula, classrooms, and so forth are all undeniably contractual responsibilities of the school. A contractual arrangement thus forms the basis of all our private educational institutions, except perhaps a few foundlings' schools. ${ }^{98}$

As noted above, ${ }^{99}$ the Court of Appeals for the Fifth Circuit found, in Cook v. Advertiser Co. ${ }^{100}$ that a standing opportunity to place social notices in a newspaper does not constitute an offer of a unilateral contract, because the Advertiser charged no fee for stories appearing on the society page and persons who submitted information for publication had no rights against the newspaper. Thus, a black who was denied publication of her announcement in the portion of the paper available to whites did not have a cause of action under section 1981. However, a parent who pays to enroll his child in a private school certainly has rights against the educators who operate the institution. The opportunity to obtain these rights is denied to a person who is refused a contract because he is nonwhite. The application of the contract concept to the private school situation is not the manipulation of a formal relationship for the purpose of opening a door to government regulation, but rather is a recognition of a substantial relationship.

\section{B. Autonomy in the Context of Private Schools}

\section{The Decision in Cook v. Hudson}

The supposed right to participate in discriminatory practices has arisen in a setting different from but related to the attacks on segregated private schools under section 1981. In Cook $v$. Hudson ${ }^{101}$ three public school teachers asserted a right under

${ }^{98}$ Marriage represents a completely different case. There is a legal contract of marriage into which the two parties enter, but that is not the foundation of the relationship. The circumstance of marriage would for the most part exist in the absence of any conception of contract and perhaps in the absence of any organized society at all.

${ }_{99}$ Text accompanying note 43 supra.

100458 F.2d 1119 (5th Cir. 1973).

${ }^{101} 365$ F. Supp. 855 (N.D. Miss.), affd, 511 F.2d 744 (5th Cir. 1973), petition for cert. filed, 44 U.S.L.W. 3230 (U.S. Oct. 1, 1975) (No. 75-503). 
section $1983^{102}$ to send their children to segregated private schools despite a school board policy denying their right to do so. The Board of Education of Calhoun County, Mississippi, acting pursuant to a desegregation order, ${ }^{103}$ adopted an unwritten policy (not required by the desegregation order but approved by the Justice Department) of not hiring or rehiring teachers, residing in the county, who sent their children to a school other than a county public school. ${ }^{104}$ Before the 1968 desegregation order there had never been a private school in the county; after the order only one, the segregated "Calhoun Academy," was established. The district court in Hudson found that the Academy had been established "to provide a haven for segregated education." 105 Subsequent to adoption of this policy, the plaintiff teachers in Hudson were not rehired, solely because they would not comply with the board rule. ${ }^{106}$

The school board adopted its policy to ensure that the faculty would be committed to a desegregated school system and that students would not "perceive rejection ... from a teacher whose own children attend a nearby racially segregated school."107 Both the district court and the Court of Appeals for the Fifth Circuit upheld the validity of the policy and the dismissal of the teachers, but on different grounds. The district court held that the board policy was valid as applied because the only private school option was a segregated school. ${ }^{108}$ The rule was rationally related to the legitimate state purpose of achieving effective, integrated public education, and therefore did not deny the teachers equal protection. ${ }^{109}$ The first amendment associational rights of public employees, the court determined,

10242 U.S.C. $\$ 1983$ (1970) provides:

Every person who, under color of any statute, ordinance, regulation, custom, or usage, of any State or Territory, subjects, or causes to be subjected, any citizen of the United States or other person within the jurisdiction thereof to the deprivation of any rights, privileges, or immunities secured by the Constitution and laws, shall be liable to the party injured in an action at law, suit in equity, or other proper proceeding for redress.

${ }^{103}$ United States v. Calhoun County Bd. of Educ., No. W€ 6637 (N.D. Miss., Aug. 9, 1968), cited in $365 \mathrm{~F}$. Supp. at 856.

${ }^{104} 511 \mathrm{~F} .2 \mathrm{~d}$ at 745 . Mississippi provides no tenure for public school teachers. Id. n.1.

105365 F. Supp. at 857.

${ }^{106} I d$.

${ }^{107} I d$. at 860 , quoted in 511 F.2d at 746.

${ }^{108} 365 \mathrm{~F}$. Supp. at 859 . The district court specifically left open the question whether such a rule would be valid if the private school in question offered a racially neutral educational advantage not available in the public schools. The court found that the purpose of the board rule was limited to dealing with the situation at hand, id. at 859-60, and did not consider the question of overbreadth.

${ }^{109} \mathrm{Id}$. at 860 . 
may sometimes be abridged if there is "clear justification" for doing so, such as the need to vindicate the fourteenth amendment rights of the county's schoolchildren who had been the victims of past segregation. ${ }^{110}$

The court of appeals affirmed, its order accompanied by a per curiam statement of the case and three separate opinions on the law. In voting to affirm, Judge Coleman cited Supreme Court decisions upholding the right of the federal government to prohibit certain political activities among its employees, ${ }^{111}$ asserting that the government policy in question need only be a good faith effort to maintain an effective school system. ${ }^{112}$ Judge Roney voted to "affirm the district court's conclusion that the school authorities acted within their discretionary authority" in attempting to lessen the detrimental influence of the existence of the Calhoun Academy on the integrated public school system. He added that the case did "not have broad implications" outside its context of court-ordered desegregation. ${ }^{113}$

Perceiving the issue differently, Judge Clark dissented because the board's rule imposed a "substantial burden upon the exercise of a fundamental right" without sufficient justification. ${ }^{114} \mathrm{He}$ objected to the finding that this policy advanced the purpose of eradicating discrimination. In Judge Clark's view the district judge gave too much weight to speculative sociological testimony. ${ }^{15}$ This weak evidence, Judge Clark concluded, should not override the teachers' otherwise protected rights of association and privacy.

2. Balancing Constitutional Interests in Cook v. Hudson

If, as Judge Coleman stated, ${ }^{116}$ the Hatch Act cases adequately resolve the problems raised in Cook v. Hudson, then Hud-

${ }^{110} \mathrm{Id}$. at 859 (citing Pickering v. Board of Educ., 391 U.S. 563, 568, 572-73 (1968) (Board of Education could fire teachers only for speech that would "have impeded the teacher's performance of his daily duties in the classroom or to have interfered with the regular operation of the school generally"); Ullmann v. United States, 350 U.S. 422 (1956); Clark v. Holmes, 474 F.2d 928, 931 (7th Cir. 1972), cert. denied, 411 U.S. 972 (1973) (first amendment rights opposed by state interest in employee discipline)).

111511 F.2d at 748 (Coleman, J.) (citing United Pub. Workers v. Mitchell, 330 U.S. 75 (1947); United States Civil Serv. Comm'n v. National Ass'n of Letter Carriers, 413 U.S. 548 (1973) (reaffirming Mitchell)). In both cases, the first amendment rights of employees were viewed in the context of the government's power to ensure its efficient, honest administration under the Hatch Act, 5 U.S.C. § 7324 (1970).

112511 F.2d at 749 (Coleman, J.).

${ }^{113}$ Id. at 750 (Roney, J.).

${ }^{114}$ Id. at 751 (Clark, J., dissenting).

${ }^{115} \mathrm{Id}$. at 752-53, 756-57 (Clark, J., dissenting).

${ }^{116}$ Id. at 748 (Coleman, J.). 
son has little relevance to the issues raised in $M c$ Crary and Riley. The guiding principle of the Hatch Act decisions is the theory that the state may have an overriding interest in regulating the speech and associations of those who voluntarily enter into public employment. That principle sheds little light on the rights of parents and teachers in the private school context. The Hatch Act cases do not, however, completely dispose of the question presented in Hudson. Instead, the Hudson decision should be viewed as depending on a balancing of the relevant first and fourteenth amendment interests, and thus is illuminating in considering McCrary and Riley.

There are significant factual distinctions between the United States Civil Service and a local school system and between regulating certain types of partisan political speech and electioneering and regulating association related to the right to bring up one's children as one sees fit. ${ }^{117}$ There are also distinctions between the nature of the government interests protected by the Hatch Act and those of the school board in Hudson. These distinctions suggest that although the general balancing approach should not be abandoned, there is insufficient basis for the suggestion by Judge Coleman in Hudson that associational and privacy interests in segregated private schools are easily overridden.

In the Hatch Act, Congress exercised its power to protect the integrity of the federal government from a widely perceived threat of corruption. This is a general governmental power; one can hardly conceive of a government that does not possess it to some degree. Yet it is a special power in the sense that its exercise is fundamental to the survival of government, though it does not advance any particular aim of government. The peculiar nature of this power precludes unexamined reliance on the Hatch Act cases to solve the problems raised by encroachment on civil liberties in the advancement of less basic governmental interests.

Were the local government's power to run an effective school system the only issue in Hudson, dissenting Judge Clark would have a powerful argument that the school board's policy should be invalidated. The important rights of association and familial privacy should not be infringed by a general govern-

117 The parent is responsible for the child's education even though the state has established schools and could conceivably have assumed responsibility. See Pierce v. Society of Sisters, 268 U.S. 510, 535 (1925): "[T]hose who nurture [the child] and direct his destiny have the right, coupled with the high duty, to recognize and prepare him for additional obligations." 
mental interest in operating schools, especially where, as here, the evidence indicates only indirectly that the policy infringing those rights advances the government's claimed interest. ${ }^{118}$

There is, however, a stronger characterization of the county's case. The nature of the power exercised by the school board is not significantly less important than the federal power underlying the Hatch Act. Besides having an interest in running its schools well, the school board in Hudson was acting to implement a court order requiring it to enforce the fourteenth amendment rights of the county's black schoolchildren. This special concern for effectively establishing the priority of equal protection in the public school system elevates the justification for the board's exercise of power to a level comparable to that underlying the Hatch Act decisions. Chief Judge Keady recognized the importance of the school district's equal protection concerns in the trial court opinion: "Conceding there must be clear justification for curtailing or limiting First Amendment rights, nevertheless, plaintiffs' rights as parents may not be considered in isolation, and to the exclusion of other constitutional demands of equal, if not greater, magnitude."119

The existence of this fourteenth amendment equal protection interest of the county schoolchildren as a basis for the board's policy places the teachers' associational and familial rights in conflict with strong forces indeed. ${ }^{120}$ If the board's policy had been invalidated in Hudson, the fourteenth amendment rights of those protected by the 1968 integration order might have been infringed. ${ }^{121}$

A conflict between constitutional rights such as the one that occurred in Hudson is rare but by no means unique. Justice Douglas attempted to avoid a similar conflict in his famous dissent in Moose Lodge No. 107 v. Irvis. ${ }^{122}$ By separating the issue of

${ }^{118} 511$ F.2d at 752-53 (Clark, J., dissenting).

119365 F. Supp. at 859 . The opinion continued (quoting Ullman v. United States, 350 U.S. 422, 428 (1956)):"As no constitutional guaranty enjoys preference, so none should suffer subordination or deletion."

120 The 1968 desegregation order issued pursuant to the fourteenth amendment is of course in accord with the spirit of the thirteenth amendment as well.

121 Of course, this does not vitiate Judge Clark's argument concerning the tenuousness of the psychological evidence supporting the board's policy. But psychological and sociological evidence has been important in showing harm under the fourteenth amendment. See Brown v. Board of Educ., 347 U.S. 483 (1954). Where the issue is whether the fourteenth amendment interests of a large number of schoolchildren will be served by a given policy, psychological evidence may be the only kind adducible.

122407 U.S. 163, 179-84 (1972) (Douglas, J., dissenting). Justice Douglas followed the dictum in his opinion for the Court in Evans v. Newton, 382 U.S. 296, 299 (1966): "A 
association from that of state action, he could affirm the right of individuals to associate with complete freedom but deny the right of discriminatory associations to receive significant government benefits available in limited supply. A majority of the Supreme Court considered this approach in Gilmore v. City of Montgomery, ${ }^{123}$ in which segregated school groups were enjoined from the exclusive use of recreational facilities. in city parks in order to guarantee full implementation of public park desegregation orders. The private segregated organizations were not enjoined from using the park, however, although the Court acknowledged that upon a finding of "impairment of an outstanding school desegregation order" such a result might be warranted on remand.

The Court was aware of the implications of its position even though no private group was ordered to integrate:

It should be obvious that the exclusion of any person or group ... from public facilities infringes upon the freedom of the individual to associate as he chooses. . . . $[\mathrm{H}]$ owever, we must also be aware that the very exercise of that freedom to associate by some may serve to infringe that freedom for others. Invidious discrimination takes its own toll on the freedom to associate, and it is not subject to affirmative constitutional protection when it involves state action. ${ }^{124}$

The Court recognized that associational rights may conflict both 
rights, ${ }^{125}$ while the dissenters in that case characterized them only as associational. ${ }^{126}$ The Hudson dissent spoke of the "personal freedom as parents to choose the academic environment in which their children will be educated," a freedom that may be "viewed as a part of a citizen's Fourteenth Amendment liberty or First Amendment freedom of association or a combination of both."127

This disparity of definition arises not from the intrinsic complexity of the interest claimed by the schoolteacher parents (one has an intuitive feel for what it is); but rather from the fact that the Supreme Court has never clearly formulated a doctrine of associational rights. Only in Pierce $v$. Society of Sisters ${ }^{128}$ did the Supreme Court consider doctrines of association and privacy in a context analogous to the one under consideration here. In Pierce the Court found these rights guaranteed by the fourteenth amendment. ${ }^{129}$ It must be noted, however, that Pierce was decided during the peak of the "substantive due process" era, when state interests were frequently afforded little weight.

Parents' decisions concerning the education of their children involve both political and social aspects of first amendment interests. Parents' decisions concerning the education of their offspring are political within the broad meaning of "politics" adopted by the Supreme Court in NAACP v. Button. ${ }^{130}$ Certainly, discussion of educational matters is protected as discussion of a subject of public interest. ${ }^{131}$ Many parents send their children to school not only because of compulsory attendance laws, but also with the hope that education will enable their children to make a "distinctive contribution"132 to society. Without doubt those who operate schools also hope this will be one result of their efforts. The decision to enroll one's child in a private school "presenting ideas or having educational methods or practices which are not available in the public schools"133 may be viewed as a political choice, as may the decision to establish such a school. Operating

125515 F.2d at 1087.

${ }^{126} 515$ F.2d at 1094-96 (Russell, Field \& Widener, JJ., dissenting).

127511 F.2d at 750 (Clark, J., dissenting).

128268 U.S. 510 (1925).

${ }^{129} 268$ U.S. at 534-35. The Pierce Court found the rights in the general principle of "liberty" and did not identify or place them more specifically. See note 164 infra \& accompanying text.

130371 U.S. 415 (1963).

131 Pickering v. Board of Educ., 391 U.S. 563, 573 (1968).

132 NAACP v. Button, 371 U.S. 415,431 (1963).

${ }^{133}$ McCrary v. Runyon, 515 F.2d 1082, 1087 (4th Cir. 1975) (en banc), cert. granted, 96 S.Ct. 354 (1975) (Nos. 75-62, 75-66, 75-278, 75-306). 
private schools, at least when they do not transgress state statutes and regulations reasonable under Pierce, ${ }^{134}$ legitimately presents the public with a choice of educational alternatives. The individual should be as free to choose among these alternatives as he is to choose among the proposed policies of candidates for election to school boards.

The associational right claimed by the parents is also social. A parent may choose a private school for his child partly on the basis of the sort of people with whom the parent wishes the child to associate. A parent may believe that a child's social environment is important to character development. Until Riley and $M c C r a r y$, no case had suggested that in the absence of state action the power of the state to regulate education included the power to prescribe who must be allowed to attend a particular private school. Pierce limits the social setting that one may seek out in a private school only to the extent of permitting the state to require that teachers be of good moral character. ${ }^{135}$

The right of social association is part and parcel of the assertedly political right discussed above. But in addition, given the absence of support for the position that the regulatory power of the state permits it to prescribe which students must be admitted to which private schools, the school's choice of the composition of its student body is a legitimate choice of educational methods. If the school has the right to present such policies to the public, then the public has a correlative right to consider those policies in choosing a school.

In addition to these associational rights, plaintiffs' rights of familial privacy, akin to those raised in Griswold, ${ }^{136}$ Roe $v$. Wade, ${ }^{137}$ Stanley v. Georgia,${ }^{138}$ and Eisenstadt, ${ }^{139}$ are involved in Hudson. Although these cases all center on the problem of sexuality, their logic need not end there. Indeed, Griswold builds the right of sexual freedom in part on the freedom to choose a

${ }^{134}$ The Pierce Court did not question

the power of the State reasonably to regulate all schools, to inspect, surpervise and examine them, their teachers and pupils; to require that all children of proper age attend some school, that teachers shall be of good moral character and patriotic disposition, that certain studies plainly essential to good citizenship must be taught, and that nothing be taught which is manifestly inimical to the public welfare.

268 U.S. at 534.

${ }^{135} I d$.

${ }^{136}$ Griswold v. Connecticut, 381 U.S. 479 (1965).

137410 U.S. 43 (1973).

138394 U.S. 557 (1969).

${ }^{139}$ Eisenstadt v. Baird, 405 U.S. 438 (1972). 
school in Pierce. ${ }^{140}$ Sex is but one of a number of concerns of such central importance to the familial relationship that it should be unregulated by government. ${ }^{141}$ The choice of educational policy is fundamental to the relationship between parent and child and to the parent's responsibility for the child. It is an intensely personal matter which in very large part should be between parent and child, and eventually between them and the school.

In summary, the right asserted by the plaintiffs in Hudson to send their children to a school of their choice consists of at least (1) an interest in familial privacy, including the freedom to bring up a child as one chooses, (2) an interest in the social association of both themselves and their children, and (3) quasi-political interests in effectively supporting a favored educational philosophy. When these rights are viewed together, the real issue is the "autonomy"142 of the parent. Professor Henkin has written:

Primarily and principally the new Right of Privacy is a zone of prima facie autonomy, of presumptive immunity from regulation, in addition to that established by the first amendment. The zone, Justice Blackmun told us, . . . consists of 'personal rights' that can be deemed 'fundamental,' that are 'implicit in the concept of ordered liberty.' The right has 'some extension' to marriage, ... family relations and parental autonomy. But we will know which rights are and which are not within the zone only case by case . . . ${ }^{143}$

Professor Henkin's formulation of autonomy focuses primarily on the four "sexual privacy" cases, ${ }^{144}$ yet his analysis applies equally well to a much larger set of rights including those examined above. ${ }^{145}$ The courts have denominated as "associational" the rights upheld in NAACP $v$. Alabama ex rel.

140381 U.S. at $482-83$.

141 On the other hand, not even the sexual relations of the family are wholly immune from state regulation. Prohibitions of incest, for example, still stand. See, e.g., Miss. Code ANN. § 93-1-1 (1972).

${ }^{142}$ This name for the collection of constitutional rights was suggested in Henkin, supra note 79, and On Privacy, supra note 79, as a useful device for analyzing the real nature of the rights involved in Griswold, Eisenstadt, Stanley v. Georgia, and Roe v. Wade. Henkin notes that these "familial" rights are less matters of "privacy" in the traditional sense of keeping one's affairs secret, than of "autonomy," meaning the ability to act free of governmental interference.

143 Henkin, supra note 79, at 1425-26.

${ }^{144}$ Cases cited notes 136-39 supra \& accompanying text.

${ }^{145}$ Text accompanying notes $49-92$ supra. 
Patterson, ${ }^{146}$ NAACP v. Button, ${ }^{147}$ and Shelton v. Tucker,,${ }^{148}$ but they can easily be seen as rights of autonomy in Professor Henkin's sense. The rights asserted by the NAACP on behalf of its members in Alabama ex rel. Patterson and the rights asserted in Shelton are rights of privacy in the traditional sense of the right to keep information about oneself secret from the government. In both cases, however, the key support for the holding was the conclusion that governmental knowledge of the association in question impaired the individual's autonomy by subjecting him to the possibility of governmental or other intimidation. ${ }^{149}$ Similarly, the limitation of autonomy in childbearing was the central issue in Roe v. Wade. ${ }^{150}$ Further, while Button involved the ability of the NAACP as an organization to catalyze litigation, the basis of the holding was that the members of the organization had a right to be free from government interference when advancing their beliefs in this manner.

As Professor Henkin states, the zone in question is only one of "prima facie autonomy, of presumptive immunity from regulation"; ${ }^{151}$ this holds true for the expanded zone of autonomy suggested here as well. The state's interest in the mother's decision to abort grows with the fetus. ${ }^{152}$ Similarly, Gilmore $v$. City of Montgomery concerned the point at which restrictions can be imposed on the autonomy of individuals to practice segregation in private groups. ${ }^{153}$ In Pierce the parents were presumed to have autonomy in the decision where to send their children to school, subject to reasonable regulation of certain aspects of education. In Shelton $v$. Tucker the Court did not foreclose the possibility of inquiry into specific memberships of teachers. ${ }^{154}$

The theoretical objection to this consolidation of concepts is that the concepts do not necessarily share a common basis. The Supreme Court in Griswold found the right of marital privacy (or autonomy) in the "peripheral rights" that emanate from the first amendment. ${ }^{155}$ The reasoning in Alabama ex rel. Patterson was

146357 U.S. 449 (1958).

147371 U.S. 415 (1963).

148364 U.S. 479 (1960).

149 Shelton v. Tucker, 364 U.S. 479, 486-87 (1960); NAACP v. Alabama ex rel.

Patterson, 357 U.S. 449, 462 (1958).

150410 U.S. 43 (1973).

${ }^{151}$ Henkin, supra note 79 , at 1425.

152 Roe v. Wade, 410 U.S. 113, 162-65 (1973).

153417 U.S. 556,575 (1974).

154364 U.S. at $487-88$.

155381 U.S. at $482-84$. 
similar. ${ }^{156}$ However, the Court in Griswold noted that the right there discovered was not an exclusive first amendment right but was also supported by the third, fourth, fifth, and ninth amendments. ${ }^{157}$ The right in Roe v. Wade is less securely tied to the first amendment; Justice Blackmun stated ${ }^{158}$ that different cases tie different parts of the right to different constitutional provisions, the first, ${ }^{159}$ fourth, fifth, ${ }^{160}$ ninth, ${ }^{161}$ and fourteenth $^{\mathbf{1 6 2}}$ amendments, along with the general concept of penumbral rights. ${ }^{163}$ Pierce itself fails to tie the right it assures to any concept more definite than that of general liberty. ${ }^{\mathbf{1 6 4}}$ It is questionable whether rights of such diverse constitutional origin are properly subsumed under the single rubric of autonomy.

Most of the majority opinions ground the rights discovered in the cases under discussion at least partly in the first amendment. ${ }^{165}$ Some, particularly Griswold and Roe v. Wade, draw much more widely from the Constitution. The Meyer $v$. Nebraska-Pierce $v$. Society of Sisters line of cases does not even find partial basis in the first amendment, and these cases present facts

156357 U.S. at $460-62$.

157381 U.S. at $481-85$.

158410 U.S. at 152.

159 Id. (citing Stanley v. Georgia, 394 U.S. 557, 564 (1969)).

${ }^{160}$ Id. (citing, inter alia, Terry v. Ohio, 392 U.S. 1, 8-9 (1968); Katz v. United States, 389 U.S. 347,350 (1967)).

${ }^{161}$ Id. (citing Griswold v. Connecticut, 381 U.S. 479, 486 (1965) (Goldberg, J., concurring)).

${ }_{162}$ Id. (citing Meyer v. Nebraska, 262 U.S. 390, 399 (1923)).

${ }^{163}$ Id. (citing Griswold v. Connecticut, 381 U.S. 479, 484-85 (1965)).

${ }^{164}$ The Pierce philosophy is best set out in a passage from Meyer v. Nebraska, 262 U.S. 390,399 (1923):

While this Court has not attempted to define with exactness the liberty thus guaranteed [by the fourteenth amendment], the term has received much consideration and some of the included things have been definitely stated. Without doubt, it denotes not merely freedom from bodily restraint but also the right of the individual to contract, to engage in any of the common occupations of life, to acquire useful knowledge, to marry, establish a home and bring up children, to worship God according to the dictates of his own conscience, and generally to enjoy those privileges long recognized at common law as essential to the orderly pursuit of happiness by free men.

Among recent jurists, at least the second Justice Harlan would not have objected to this approach, believing as he did that the proposition that all constitutionally protected rights must be tied, however tenuously, to some provision more specific than this guarantee, might permit certain rights "implicit in the concept of ordered liberty" to be excluded from fourteenth amendment protection. See Griswold v. Connecticut, 381 U.S. 479, 499 (1965) (Harlan, J., concurring).

165 The exception of the fourth and fifth amendment cases is not important for purposes of this Comment. See, e.g., cases cited note 92 supra. These mostly criminal cases generally guarantee the traditional sense of privacy, meaning the right to be free from others' prying into one's affairs. 
most closely analogous to our current concerns. The opinions speak generally of the fourteenth amendment guarantee of liberty. ${ }^{166}$ They were written during the heyday of economic substantive due process in the 1920's, however, and their rationales probably did not survive the demise of that doctrine. Indeed, Meyer stresses the teacher's right to pursue a vocation, ${ }^{\mathbf{1 6 7}}$ and Pierce emphasizes the property and business interests of the school. ${ }^{168}$ The general reliance on the liberty guaranteed the parents by the fourteenth amendment in Pierce is a close analogue to this reasoning. Yet no one suggests that the results of Meyer and Pierce are no longer law; the Griswold Court cited both with approval. ${ }^{169}$ Meyer and Pierce are of course completely compatible with the new cases proclaiming associational and privacy rights. They have been absorbed into the new jurisprudence of the Bill of Rights, and one suspects if they were to be decided today, their language would closely resemble that of the privacy and association cases. The rights identified in all these cases remain at least presumptively with the people because of the ninth amendment. ${ }^{170}$

Another objection to this formulation of the right of autonomy is that the sort of individual interests involved in sexual relations and political association, for example, are too diverse to be protected by a single right. Yet in each case the issue is the same: whether in the context of one's sexual intimacies, political associations, or other activities there is a right, arising from the first amendment and other provisions of the Bill of Rights, to act autonomously, that is, without government interference. ${ }^{171}$ That we have different reasons for wishing our actions to be free of governmental regulation in different contexts no more proves that the autonomy sought consists of several parts than that our having different interests in speaking freely and on different subjects proves that there is more than one right of free speech;

166 See note 164 supra.

167262 U.S. at 400.

168268 U.S. at 534-35.

169381 U.S. at 481, 482; also cited with approval in Eisenstadt v. Baird, 405 U.S. 438, 457 (1972) (Douglas, J., concurring).

${ }^{170}$ See Griswold v. Connecticut, 381 U.S. 479, 486 (1965) (Goldberg, J., concurring).

171 The question whether this is a resurrection of substantive due process cannot be fully explored here. It is not a revival of economic substantive due process, whose abuse led to the decline of the doctrine. Note also that the interests of individuals in acting autonomously in the situations under consideration have been tied to guarantees in the Bill of Rights more specific than general liberty, or at least has been found in the penumbras of such guarantees. 
the right to discuss politics and the right to discuss personal matters are the same. The difference between the cases is that there are different government interests pitted against the right of autonomy. Thus the balances struck may be different in each case. A theoretical basis for the right of autonomy, unified in its central features if not in all details, has thus been laid.

\section{Reconciliation of Constitutional Interests}

The perennial problem of constitutional litigation is determining when an individual constitutional interest is outweighed by a conflicting state interest. Many court opinions and much commentary have sought to determine when the state interest must be "compelling" and the means used to achieve it "necessary," when the interest must be "substantial," and when it need merely be "legitimate" and the means to achieve it "rational." Such a determination is arduous, and, as is evidenced by the splits of opinion on the Supreme Court, an unscientific undertaking. ${ }^{172}$

Fortunately, the facts of Hudson allow us to short-circuit most of the inquiry because of the nature of the state's interest. The most significant state interest involved here is the protection of the right to equal protection of each of the black schoolchildren of Calhoun County. The countervailing right of autonomy is accurately characterized as presumptive or prima facie; it contains a built-in acknowledgement of limitation. The right of black people to equal protection of the law has never been found less important than any other interest; ${ }^{\mathbf{1 7 3}}$ the balance struck in Hudson does not depart from precedent.

\section{Autonomy and Thirteenth Amendment Rights in the McCrary Situation}

The kind of constitutional balancing required for analysis of

172 See generally, e.g., San Antonio School Dist. v. Rodriguez, 411 U.S. 1 (1973) (majority opinion and opinion of Marshall, J., dissenting); Dandridge v. Williams, 397 U.S. 471 (1970) (majority opinion and opinion of Marshall, J., dissenting); Harper v. Virginia Bd. of Elections, 383 U.S. 663 (1966); Railway Express Agency, Inc. v. New York, 336 U.S. 106 (1949); Korematsu v. United States, 323 U.S. 214 (1944).

${ }^{173}$ In only one modern case has state discrimination based on race been found supportable, and that case arose in a tense wartime atmosphere. See Korematsu v. United States, 323 U.S. 214 (1944). The refusal of the Supreme Court in Gilmore v. City of Montgomery, 417 U.S. 556 (1974), to grant injunctions against the nonexclusive use of public recreation facilities by discriminatory groups was not a denial of the paramount nature of fourteenth amendment rights, but an admission by the Court that it lacked sufficient information to decide whether such use sufficiently implicated the city in the discriminatory practices of the groups to constitute state action. 
Hudson ${ }^{174}$ can be applied to McCrary ${ }^{175}$ and Riley ${ }^{176}$ as well. The constitutional conflict in these two cases is even sharper than in Hudson or Gilmore. ${ }^{177}$ In the former cases two private parties asserted conflicting individual rights, whereas in the latter cases local governments asserted the rights of others. The method used above to short-circuit the inquiry into degrees of constitutional interest and necessity of particular means will be even more useful here. The conflicting rights have closely analogous constitutional bases, thus intensifying the value judgment required to dispose of these cases.

The claim of the plaintiffs in McCrary and Riley is that a statute, section 1981 of title 42 of the United States Code, protects nonwhites from racial discrimination in contract formation by private parties. The constitutional provision granting Congress power to afford them this protection is the thirteenth amendment, which explicitly forbids slavery but has been held to allow Congress also to prohibit any practice that it rationally determines imposes badges or incidents of slavery, particularly on black persons. ${ }^{178}$ The power exercised by Congress here is very specific: It is the power to enact appropriate legislation to prevent whites from imposing badges of slavery on nonwhites by refusing to contract with them. The right claimed by plaintiffs, although statutory, carries the imprimatur of the thirteenth amendment; without that amendment the right would probably be beyond the power of Congress to guarantee, at least to the extent that it applies to purely private discrimination. ${ }^{179}$ Congress enforces the thirteenth amendment right to live as a free individual under the jurisdiction of the United States by enforcing a right to make private contracts not directly protected by the Constitution; one personal right gives effect to another.

This relationship of rights and power is different from that

174 Cook v. Hudson, 511 F.2d 744 (5th Cir. 1973), petition for cert. filed, 44 U.S.L.W. 3230 (U.S. Oct. 1, 1975) (No. 75-503).

175 McCrary v. Runyon, 515 F.2d 1082 (4th Cir. 1975) (en banc), cert. granted, 96 S. Ct. 354 (1975) (Nos. 75-62, 75-66, 75-278, 75-306).

${ }^{176}$ Riley v. Adirondack Southern School for Girls, 368 F. Supp. 392 (M.D. Fla. 1973), appeal docketed, No. 74-1976, 5th Cir., Apr. 15, 1974.

177 Gilmore v. City of Montgomery, 417 U.S. 556 (1974).

${ }^{178}$ Jones v. Alfred H. Mayer Co., 392 U.S. 409, 440-43 \& n.78 (1968) (overruling prior constitutional construction of $\S 1981$ and upholding $\S 1982$ as a rational measure aimed at eliminating badges and incidents of slavery). See Johnson v, Railway Express Agency, Inc., 95 S. Ct. 1716, 1720 (1975); Tillman v. Wheaton-Haven Recreation Ass'n, 410 U.S. $431,439-40$ (1973).

179 It has not been claimed that $\$ 1981$ could be enacted under the commerce power, because the statute is not limited to contracts affecting commerce. 
usually involved in the enactment of a law. For example, when Congress enacts a statute pursuant to the commerce power, it may create in certain individuals statutory rights. ${ }^{180}$ But those rights are based on the grant of a general governmental power to Congress, not the grant of a power to enforce a specific constitutional right; the grant of the commerce power to Congress does not create in individuals a right to a well-regulated economy, and statutory rights granted to individuals thereunder are not found on individual constitutional rights. ${ }^{181}$ The contrast between the two types of powers does not suggest that absent congressional action, there would be an independent right in individuals to the protection now afforded by section 1981 . The Supreme Court has held that the congressional power rationally to determine the badges and incidents of slavery is part of congressional power to enforce the thirteenth amendment. ${ }^{182}$ Congress would not need this power if the thirteenth amendment granted a self-executing right to be free of such badges. This analysis of the right asserted by the McCrary and Riley plaintiffs does not depend on whether the statute is interpreted in a "limited" or "unlimited" fashion ${ }^{183}$ as long as either reading gives effect to a power of Congress rationally exercised. Once the courts have satisfied themselves as to the meaning and rationality of the statute, the right guaranteed is confirmed as a protection appropriate to the enforcement of the freedom guaranteed by the thirteenth amendment.

The opposing right claimed by the McCrary and Riley defendants is the right of autonomy discussed above in the context of Cook v. Hudson. ${ }^{184}$ The right has two aspects: first, there is the right of parents to send their children to the type of school that they see fit, which defendants assert on the parents' behalf; second, there is the right of defendants themselves to operate a school according to their best judgment. The first aspect is the same as the right asserted by plaintiffs in Hudson; the second

${ }^{180}$ E.g., the National Labor Relations Act, 29 U.S.C. § 151 et seq. (1970), granting workers rights to engage in certain concerted activities without fear of employer retaliation.

${ }^{181}$ For example, workers have no superstatutory (constitutional) right to be free from economic pressure from employers; the NLRA alone creates that right, see note 180 supra.

182 Jones v. Alfred H. Mayer Co., 392 U.S. 409, 440-41 (1968).

${ }^{183}$ See text accompanying notes $187,200-08$ infra.

${ }^{184}$ Since the demise of economic substantive due process, the defendants cannot claim that $\S 1981$ interferes unreasonably with their business interest in running a school as they wish. 
recalls the rejected economic substantive due process theories of Pierce and the early economic regulation cases. Education, however, is more than just a business. All education involves teaching debatable ideas and values as well as facts; this is never truer than in private general elementary and secondary education offered and selected as an alternative to public school methods or ideas.

Thus, segregated education may involve association for the purpose of propagating a social, political, and moral philosophy, the type of association protected in NAACP $v$. Button. ${ }^{185}$

The rights of both plaintiffs and defendants in these cases belong to those sets of rights necessary to the enforcement of the rights explicitly granted individuals by the Constitution. Although the rights claimed by plaintiffs were created by Congress while those asserted by defendants were "discovered" by the courts, the relationship of each right to the Constitution is the same: Each buttresses the enforcement of explicit rights.

Because of this similarity, the analysis of each right in terms of "compelling interest," "fundamentality," and so forth need not be carried out in detail; ${ }^{186}$ the relative constitutional weight of the rights cannot be determined. Which right is more important must be determined not in the abstract, but in the particular factual situation, in terms of both policy and ethics.

The "unlimited" reading of section 1981 asserts that any act of racial discrimination in the formation or performance of contracts constitutes an insult to the individual against whom the discrimination is directed, ${ }^{187}$ sufficient to constitute a badge of slavery. Acts of insult differ in the amount of harm done, which determines the amount of damages awarded or the type of injunction granted. In all cases, however, the type of injury is considered the same, so that all plaintiffs have the same degree of interest in vindicating constitutional rights. This formulation answers the $\mathrm{McCrary}$ dissenters' contention that certain denials of contracts are more important than others, and that only impor-

185371 U.S. 415 (1963); see NAACP v. Alabama ex rel. Patterson, 357 U.S. 449 (1958).

Moreover, the fact that neither the majority nor dissenting opinion in McCrary distinguishes between the rights of the defendant educators and those of the parents of the children they teach indicates that these rights are fundamentally the same. The rights of the two groups, if not identical are at least complementary. But $f f$. Wisconsin v. Yoder, 406 U.S. 205, 241-46 (1972) (Douglas, J., dissenting in part).

${ }^{186}$ See text accompanying note 172 supra.

187 Note that the damages awarded in $M c$ Crary were for humiliation, embarrassment, and mental anguish. 515 F.2d at 1089. 
tant denials are forbidden by section 1981; the right to contract to send one's child to a private school is not protected, because an adequate integrated public school system is available. Under the "unlimited" reading of section 1981, discrimination is forbidden not because it may prevent a black person from attaining one of his goals, but because it brands the victim with the odium of slavery. If acts of discrimination that cause the smallest actual injury are to be regarded as equivalent to those causing the largest, then the fact of the insult itself must be extremely powerful; an interest of the discriminator in exercising any other constitutional right will need to be extremely strong in order to overcome it.

In $M c$ Crary the level of defendants' interest in autonomous action is high. A restriction of autonomy in choosing a school for one's children limits the parents' ability to associate for purposes that are more than colorably political, to associate for social purposes, and to make decisions concerning intimate familial matters, any one of which enjoys constitutional protection.

The interests of plaintiffs and defendants not only have equally weighty constitutional bases, but they bear comparable rank among the rights that could logically be supported by those bases. The conflict can be resolved only by considering the consequences of affirming or reversing McCrary. A reversal would undoubtedly be formulated to allow the section 1981 and 1982 cases decided to date to remain standing. ${ }^{188}$ Under the new formulation, certain types of racial discrimination practiced by private parties, though as invidious as any other discrimination, could not be reached by Congress because of the shield of autonomy that protects the discriminators. Protection would extend not only to discrimination involving essentially private interests, such as whom one will marry or with whom one will form a drinking club, ${ }^{189}$ but also to discrimination in which the interests are more public, such as what type of education will be available to the children of a community. ${ }^{190}$ These consequences follow if infringement of defendant's autonomy rights cannot be justified by the need to serve the thirteenth amendment interests

${ }^{188}$ E.g., Johnson v. Railway Express Agency, Inc., 95 S. Ct. 1716 (1975); Tillman v. Wheaton-Haven Recreation Ass'n, 410 U.S. 431 (1973); Sullivan v. Little Hunting Park, Inc., 396 U.S. 229 (1969); Jones v. Alfred H. Mayer Co., 392 U.S. 409 (1968).

${ }^{189}$ Cf. Moose Lodge No. 107 v. Irvis, 407 U.S. 163 (1972).

${ }^{190}$ Cf. Gilmore v. City of Montgomery, 417 U.S. 556, 575 (1974), in which the Court expressed the concern that complete enforcement of one's right of association may derogate someone else's. 
protected by section 1981. A decision upholding the rights of defendants in McCrary would in no way reflect a return to the doctrine of Plessy $v$. Ferguson, ${ }^{191}$ but only the position that there are certain types of discrimination, linked to personal preferences, that the body politic cannot and should not attempt to eliminate.

Should the McCrary holding be affirmed, the Supreme Court will be extending the constitutional commitment to end racial discrimination as a relic of slavery. The question is whether this extension would carry with it a license to invade other constitutional liberties too deeply. The dissenters in McCrary ${ }^{192}$ and Hudson ${ }^{193}$ feared that associational values would be infringed too easily and often in the future, for reasons that are not compelling. The $M c$ Crary dissenters, as noted above, feared that this decision would lead to an abuse of the concept of contract as a door opener to governmental regulation and coercion of unwilling co-contractors. ${ }^{194}$

These fears are justified, if at all, only in regard to the power of Congress and the courts to eliminate racial segregation and other badges of slavery. ${ }^{195}$ The logic of $\mathrm{McCrary}$ would not lead to a wholesale expansion of the government's ability to invade private lives. Although the McCrary holding could be used to justify infringing certain personal rights in a substantial manner solely to vindicate another's personal right, no court will hold, for example, that a disappointed nonwhite suitor has an action under section 1981 against a white for refusal to marry. The interests are too intensely personal and, although narrower, far stronger than even the parents' interests in McCrary and Hudson.

\footnotetext{
191163 U.S. 537 (1896).

192515 F.2d at 1093-96 (Russell, Field \& Widener, JJ., dissenting).

193511 F.2d at 755-57 (Clark, J., dissenting).

194515 F.2d at 1093 (Russell, Field \& Widener, JJ., dissenting).
}

195 The post-Civil War amendments are peculiar constitutional provisions. They were intended to protect the rights of a particular class of citizen. The thirteenth amendment is the only constitutional provision that, in terms, guarantees individual rights against infringement by other individuals. Originally, the rights created by Congress pursuant to this amendment were meant to protect blacks from a return to slavery after the Civil War, see Civil Rights Cases, 109 U.S. 3 (1883); since then the amendment has been used to attack various systems of involuntary labor, e.g., Selective Draft Law Cases, 245 U.S. 366, 390 (1918); Clyatt v. United States, 197 U.S. 207 (1905). No serious attempt has been made, however, to suggest that the power to eliminate badges and incidents of slavery extends beyond the power to eliminate all traces of racial discrimination or discrimination against some other class in danger of falling into slavery. The holding in McCrary would permit only invasions of autonomy that can effect an end to racial discrimination. There is no license to invade freedoms for any other purpose. 
Less extreme cases can be imagined, however, to which the logic of $\mathrm{McCrary}$ might but should not automatically apply. Prototypical is the case of the private club. If the interests of parents and educators may be overridden in the name of racial integration, why should private clubs with mere social interests be allowed to discriminate when their relationships are contractual in nature? The only response is that there may not be sufficient reason or societal interest in prohibiting such clubs from discriminating. A more extreme example would arise if Congress prohibited racial discrimination by political parties, because political powerlessness is undeniably an accoutrement of slavery, in cases in which the fourteenth amendment would not restrict the party members' freedom of association. ${ }^{196}$ Here the public interest in and impact of the activity is greater, but the first amendment protection is also greater because explicit. ${ }^{197}$ The Supreme Court should acknowledge that a separate balancing of interests must be essayed in each case. Without such a caveat, courts may find it too easy to sacrifice rights of personal autonomy on the altar of ending racial discrimination.

The reasoning of $M c C r a r y$, even if carried to its extreme, does not license destruction of any and every right to act autonomously in the name of equality. Nor does it imply that unwilling co-contractors can constitutionally be coerced into accord for any and every reason. It does not even permit any and every constitutional right to be invaded in order to eliminate badges of slavery. The holding of $\mathrm{McCrary}$ does not even imply that Congress may invade all protected areas of life in order to destroy the badges of slavery. The majority admits that section 1981 cannot prevent the teaching of any doctrine. ${ }^{198}$ The ability of Congress to determine and destroy badges and incidents of slavery does not extend to a direct denial of a right explicitly stated in the Constitution. A church whose dogma included racial separatism could not be required to accept black members in order to eliminate a badge of slavery.

Thus the holding of McCrary allows Congress and the courts to declare: Race is not an absolutely protected basis of association, and certain interests in freedom of action must give way

${ }^{196}$ See Terry v. Adams, 345 U.S. 461 (1953).

${ }^{197} C f$. O'Brien v. Brown, 409 U.S. 1 (1972) (but note that this was "not a case in which claims are made that injury arises from invidious discrimination based on race in a primary contest within a single State," as was Terry $v$. Adams, id. at 4 n.1); National Socialist White People's Party v. Ringers, 473 F.2d 1010 (4th Cir. 1973).

198515 F.2d at 1087. 
before an interest in eliminating racial inequality. The thirteenth amendment does not permit congressional interference with any other constitutional right for any other reason. There is no analogous constitutional provision under which Congress will be able to use the reasoning of $M c$ Crary in order to invade protected rights. ${ }^{199}$ If carefully explained and expressly restricted, the reasoning of the majority in $\mathrm{McCrary}$ threatens to infringe only a limited set of personal liberties in a limited number of situations. Under the present state of the law, in view of the vital nature of the struggle against the relics of slavery, the delicate balance tips in favor of affirmance.

\section{A Suggested Principle of Limitation for Section 1981 and Its Application to McCrary and Riley}

Although this Comment has suggested that an affirmance of McCrary v. Runyon would not necessarily injure essential American liberties, such injuries could conceivably result from a broad construction of McCrary and section 1981. An alternative solution, rather than simple affirmance or reversal, might better protect all the interests at stake. For this reason, a construction of section 1981 will be suggested that allows it to operate in most cases in which its effect would be most useful but limits its potential for abuse.

The conventional analysis of section 1981 rests on the determination that any racial discrimination in the formation or performance of a contract humiliates the rejected party, and that the Constitution allows Congress to provide an action to redress such humiliations. ${ }^{200}$ If the requisite facts are proven, this action can be defeated only by showing that the remedy it provides would severely infringe other important rights of the discriminator. According to this reasoning the fact that some acts of discrimination result in greater injury than others is considered only in fashioning a remedy. The analysis that follows will suggest that the real badge of slavery imposed by discrimination in contracting is not the insult to the rejected party but the actual burden that such discrimination imposes on an individual. Sec-

199 See note 195 supra.

In some ways the $\mathrm{McCrary}$ holding is less dangerous to private rights than a holding based on a public function theory of state action. But see Private Education, supra note 3; Academies, supra note 8 . The result under a state action theory would infringe individual liberties no less than the $M c C r a r y$ result, but it would permit more analogies than the $\mathrm{McCrary}$ reasoning and therefore more invasions of personal liberties.

200 See note 187 supra. 
tion 1981 should protect primarily against the imposition of such burdens.

The courts in Riley and McCrary read the phrase "right to contract" such that the right is infringed whenever one is refused a contract on the basis of race. This reading, alternative to the pre-Jones ${ }^{201}$ reading that the right is violated only when the state refuses to give legal effect to a contract because of the race of one or both parties, ${ }^{202}$ is not the only reasonable alternative. The simple refusal of an individual or organization to contract with another does not necessarily deprive the rejected party of his freedom, because the latter may be able to go elsewhere with little inconvenience or diminution of acceptable options. On the other hand, for example, "when racial discrimination herds men into ghettos and makes their ability to buy property turn on the color of their skin, then [the exclusion of Negroes from white communities] too is a relic of slavery." 203 When nonwhites are in an inferior market position, the refusal of a white to contract with a nonwhite indeed imposes a substantial burden upon the nonwhite. The inferior bargaining position of the black is then a badge of slavery which marks him in all aspects of his business and social life. ${ }^{204}$

A far different situation would exist if the income and employment levels of blacks were equivalent to those of whites and if blacks were not largely confined to inferior housing in urban ghettos or depressed rural areas. Then the refusal to sell land to a black, or to hire him for a job, would not bear such long-term consequences and would not contribute to a string of insults to the black person's dignity.

An inferior position in a given market is defined essentially as one's inability to make and enforce contracts as favorable as those available to most other contractors in the same market. When such a general disability is attributable to a factor complete-

201 Jones v. Alfred H. Mayer Co., 392 U.S. 409 (1968).

202 See text accompanying notes 29 \& 30 supra.

${ }^{203}$ Jones v. Alfred H. Mayer Co., 392 U.S. 409, 442-43 (1968).

204 The Jones Court recognized the importance of racial restrictions in the private housing market, though the holding does not depend on this recognition. Similar observations might have been made about the job market, to which the Court has recently applied § 1981. Johnson v. Railway Express Agency, Inc., 95 S. Ct. 1716 (1975). Congress recognized the inferior position of nonwhites in the job and housing markets in Title VII of the 1964 Civil Rights Act, 42 U.S.C. $\S 2000 \mathrm{e}$ et seq. (1970), and Title VIII of the 1968 Civil Rights Act, 42 U.S.C. $\$ 3601$ et seq. (1970). (These acts were based on the commerce power rather than the thirteenth amendment. See Heart of Atlanta Motel, Inc. v. United States, 379 U.S. 241 (1964); Katzenbach v. McClung, 379 U.S. 294 (1964).) 
ly beyond the control of the actor, such as the accident of race, his right to contract is denied more clearly than when he is merely denied the opportunity to make a single contract for the same reason. When such a blanket disadvantage exists, a class of contracts is closed to the actor or open to him only on unfavorable terms, ${ }^{205}$ so that his range of options is substantially narrowed. $\mathrm{He}$ is presented with a genuine obstacle to achieving a legitimate personal or business goal because of race, and such an obstacle is an incident of slavery.

It may be more difficult to establish the generally inferior position of blacks in the education market than in the housing or employment markets. Because of the tradition of local control of education, patterns in education markets may be much more fragmented than in jobs or housing, so that courts will not be able to take the kind of "judicial notice" of educational conditions that they have taken in the other fields. ${ }^{206}$

If in a given case a black plaintiff proves that he was denied a contract for education on the basis of race and that because of this he was placed in an inferior position in the market for education, he has made out a far stronger case for relief than a person who asserts only a denial of contract based on race. Colin Gonzalez, one of the plaintiff children in McCrary, in fact gained admission to another private school in the area. ${ }^{207}$ Although the fact of making a single contract is no more proof of good market position than is a single denial proof of a bad one, at least it demonstrates that the plaintiffs may have retained the ability to pursue desired options as effectively as most other contractors in the marketplace. If this is true, their right to contract has not been infringed in the sense under consideration. If, however, their ability to find a school to their liking is substantially inferior to that of similarly situated whites, then their right to contract for the purpose of education has been infringed.

If the "right to contract" is interpreted as the right to an equal position in the marketplace, which in this context means a choice of schools substantially as wide as that enjoyed by whites on equally favorable terms, then either an additional evidentiary requirement has to be imposed on plaintiffs in order to prove a

${ }^{205}$ The unfavorable terms would not necessarily have to be, and usually would not be, economic terms. Rather, school administrators or admissions officers might avail themselves of more subtle, perhaps psychological, means of establishing their authority over black students that they would not employ with white students.

${ }^{206}$ See note 204 supra.

207363 F. Supp. at 1202. 
cause of action, or an additional defense would have to be available to their adversaries. Plaintiffs in cases like $M c$ Crary might be required to show disadvantage in the education market; alternatively, defendants who have discriminated might be allowed to show that their victims suffered no market disadvantage. Justice requires that the market showing be asserted as a defense rather than as an additional part of the plaintiff's burden. Discrimination, even when arguably legal, is repugnant to the national moral sense as expressed in the thirteenth amendment to the Constitution; an individual claiming a right to discriminate should be required to prove the harmlessness of his actions in the market terms described above. ${ }^{208}$

The form that the market evidence must take will have to be developed in the cases. Proof for a McCrary-type plaintiff might be relatively easy in a locality like that of Cook $v$. Hudson, where the only non-public school available is segregated;209 it would be quite difficult for a defendant there to prove no damage from his discrimination. Proof of effect may be even easier in areas where there are many segregated academies and little public support for predominantly black public schools. ${ }^{210}$ In other areas, where many private schools are integrated, problems of proof will be more difficult. For example, simply showing a disproportion of the number of whites and blacks at private schools in an area may not prove a market effect of discrimination or rebut evidence showing no effect. Disproportions will need to be shown after controlling for those factors normally associated with private school entrance qualifications, such as ability to pay, tested I.Q. level (at certain types of school), religion (if the local private education market is dominated by religious schools), and others. These disproportions will not always need to be shown at

${ }^{208}$ A similar shift of burden has been approved by the Supreme Court in Griggs v. Duke Power Co., 401 U.S. 424 (1971). In employment cases under Title VII of the Civil Rights Act, 42 U.S.C. $\S 2000$ et seq. (1970), once a plaintiff shows the discriminatory effect of an employment practice, the defendant employer must demonstrate that the practice has a business justification. The plaintiff need not show that the employer had discriminatory motives.

${ }^{209}$ Note 105 supra \& accompanying text.

Whether public schools are part of the relevant market for these purposes depends on the schools in question. For example, if a public school provided education of the same kind and quality as a private school in the same locale, it would be part of the same market. (An incidental benefit to the public schools might flow from this formulation: If public schools had to be equal in quality to the private schools in order to maintain the right of the private schools to remain segregated, parents who wish to send their children to segregated private schools would have less reason to oppose supporting the public schools with their tax dollars.)

${ }^{210}$ See Academies, supra note 8. 
the allegedly discriminatory school, but at the other private schools in the locality.

The advantages of this reading of "right to contract" are fairly clear. It requires proof of actual damage to the plaintiff in one of his activities, transforming the content of "badge of slavery" from insult to more concrete harm. Some private discriminatory conduct will not be reached under this reading, but discrimination will be reached whenever defendants fail to establish that their conduct did not hamper plaintiffs' ultimate attainment of their goals. Most importantly, this theory will substantially reduce the objections to enforcement of section 1981 which may tend to limit rights of autonomy. As the Supreme Court has noted, upholding certain associational rights may be at the expense of others' associational rights. ${ }^{211}$ Enforcement of "equality rights," which substantially restricts another individual's actions or opportunity for action, can be justified more easily when concrete, objectively discernible injury is required than when the only injury is insult. When this type of proof is required, it will be more acceptable to shift the balance to favor the rights of plaintiffs under the thirteenth amendment more heavily against discriminators claiming rights of autonomy. Of course, interpreting section 1981 in this way will not diminish the infringement of rights of autonomy in cases in which plaintiffs prove that they were disadvantaged in obtaining a quality education to their satisfaction; the interpretation suggested here will only decrease the number of successful plaintiffs and affected defendants. Should a plaintiff force desegregation of the Calhoun Academy of the Hudson case, the autonomy rights of parents, educators, and students will be infringed to exactly the same degree under this interpretation as under the McCrary majority's reading of the statute.

The suggested interpretation of section 1981 contains some disadvantages. First, it is inconsistent with the theory of most of the section 1981 cases decided to date, which hold the statute to be violated whenever a black cannot make a contract because of his race. ${ }^{212}$ Results under the suggested reading will, however, mostly be consistent with the results of most of these cases; they will differ only when plaintiffs fail to prove adverse consequences in the market.

Second, and more importantly, this reading would intro-

211 Gilmore v. City of Montgomery, 417 U.S. 556, 575 (1974).

212 See notes $38-47$ supra \& accompanying text. 
duce an anomaly into the law in that it might be difficult for the prospective defendant to predict the legal consequences of his behavior. Whether a single discriminatory act would be actionable under the proposed reading of section 1981 would depend on factors beyond the control of the discriminator, such as whether and to what extent other individuals and organizations providing the same service discriminate. ${ }^{213}$ The potential discriminator might not know about racial conditions in the relevant market. Although it is regrettable that one may not know the consequences of one's conduct in all cases, the strong constitutional and societal position against racial bias dictates that the courts not be unwilling to require discriminators to act at their own risk.

Another difficulty arises in defining the relevant market. In an area such as private education the differences between institutions are often significant because the whole object of the enterprise is to provide alternatives to standardized public school methods. For example, assume that a nonwhite sought to place his child in a "three R's" school in a community in which several progressive private schools were integrated, most of the traditional schools were not, and the public schools were grossly inferior. A court should probably hold that because educational decisions generally are protected by the right of autonomy, the plaintiff's assertion that he sought only a conservative school must be respected as a legitimate choice; the smaller group of traditional private schools would be the relevant market. This process of definition must be undertaken on a case by case basis.

A final difficulty, more political than legal, is that the suggested reading of section 1981 would probably force many Southern private schools and schools in small communities to integrate while leaving the North and schools in cities virtually untouched. ${ }^{214}$ Some degree of regional ill-will would doubtless redound from this policy, but not as much as there might have

${ }^{213}$ For example, assume a market of three equivalent private schools. Defendant school is segregated but takes every white who applies. The other schools are integrated but accept only students who score above 100 on a standardized admissions test. Plaintiff scored below 100, was denied admission to the defendant school, and could thus make out a case under the suggested formulation. A black student who scored above 100 , however, would not have a successful cause of action because of the existence of the other schools which would have admitted him.

Under this approach the general injunction against discrimination presently employed in $\S 1981$ cases, including $\mathrm{McCrary}$, might not be appropriate. Injunctions would have to be tailored more closely to particular situations.

${ }^{214}$ Note that this is also a problem with the public function theory of state action suggested in Academies, supra note 8, and Private Education supra note 3. 
been before the federal courts became as concerned with de facto segregation in the North as with the more formal discriminatory schemes in the South. ${ }^{215}$

In summary, the suggested reading of section 1981 has both advantages and drawbacks. It must be decided whether the added protection given rights of autonomy justifies section 1981's constricted coverage of private discrimination, the increased complexity of litigation, and the introduction of certain anomalies into the law. If, however, this reading is adopted, rights of autonomy claimed by discriminating educators and parents will not stand when the requirements of the rule are satisfied. This rule would require that the judgment in McCrary be vacated and the case remanded for findings about the education market in Northern Virginia. ${ }^{216}$

\section{Conclusion}

When discrimination in private education exists, it imposes a badge of slavery on the victims according to the sense of that term since Jones $v$. Alfred H. Mayer Co. ${ }^{217}$ Most courts that have interpreted section 1981 have reasoned that any discrimination in private education based on race imposes a badge of slavery. The difference between the formulation followed in McCrary and that developed in this Comment is in the degree of actual damage that must be shown in order to merit relief under the statute. The more stringent requirement of concrete harm is preferable because it ensures that constitutional rights will be invaded only when their exercise would occasion serious infringements of others' constitutional right to equality of treatment under the law.

${ }^{215}$ See, e.g., Keyes v. School Dist. No. One, 313 F. Supp. 61 (D. Colo. 1970) (opinion on the merits) and 313 F. Supp. 90 (D. Colo. 1970) (opinion on remedies), aff'd in part and rev'd in part, 445 F.2d 990 (10th Cir. 1971), modified and remanded, 413 U.S. 189 (1973).

${ }^{216}$ If the Court of Appeals in Riley reverses the trial court's finding of fact, a similar factual determination would have to be made on remand there.

217417 U.S. 556 (1974). 